\title{
Myten om Grundtvigs indflydelse på den danske folkeskole
}

\author{
Thorstein Johannes Balle
}

Historikeren Jes Fabricius Møller skriver i sin bog Grundtvigianismen i det 20. århundrede: "Grundtvigs betydning er først og fremmest symbolsk" (Møller 2007, 11). Møller udreder bl.a., hvordan denne symbolske betydning viser sig på en række områder i samfundet, herunder på skoleområdet, hvor der går en direkte indflydelseslinje fra Grundtvigs tanker til højskolen og friskolen. Nedenstående artiklen godtgør på grundlag af en gennemført interviewundersøgelse, hvordan der også, når det drejer sig om folkeskolen, er forestillinger om Grundtvigs indflydelse, hvor han får karakter af et symbol. Forestillingerne om Grundtvigs indflydelse på folkeskolen bliver her defineret som en myte, fordi de langt fra baserer sig på viden om Grundtvigs tanker, men alligevel, af ideologiske årsager, hævdes at være grundtvigske. Grundtvigs symbolske betydning på folkeskoleområdet viser sig som en aktiverende myte, og konklusionen er, at myten om Grundtvigs indflydelsen i praksis har og har haft større betydning for skolens hverdag og udvikling, end Grundtvigs tanker i sig selv.

\section{Indledning}

"Jeg ved ikke noget om Grundtvig, men selvfølgelig har han haft indflydelse på den danske folkeskole!" Sådan udtalte værten ved et middagsselskab, jeg deltog i, og lagde tryk på ordet "selvfølgelig". Ved den efterfølgende samtale var det tydeligt, at værten ikke havde noget kendskab til Grundtvigs tanker og skrifter. Desuden havde han heller ikke på nogen systematisk måde beskæftiget sig med skoleforhold. Hans udtalelser om 
Grundtvigs virkningshistorie havde altså en anden baggrund end et faktuelt kendskab til Grundtvig eller folkeskolens udviklingshistorie.

Lødigheden af værtens udsagn om Grundtvigs virkningshistorie ligner lødigheden af mange andre udtalelser om Grundtvigs virkningshistorie. Som eksempel kan fremdrages en række udsagn, som blev fremsat af professor på SDU Peter Dahler-Larsen på undervisningsminister Bertel Haarders Sorø-møde i 2007. Her sagde Dahler-Larsen bl.a., at evalueringskulturen i det danske skolevæsen skal ses på baggrund af, at vi er "midt i en ganske bestemt dansk skoletradition med tilhørende selvforstålse". Han hævdede endvidere, at denne skoletradition først og fremmest skyldes Grundtvig, idet: "Ingen enkeltperson har mere end Grundtvig præget denne skoletradition - og måske hele den danske selvforståelse. Derfor er mit emne - spændingsforholdet mellem den grundtvigske arv og krav om evalueringskultur - både vigtigt og vanskeligt" (Undervisningsministeriet 2007, 34).

I møderapporten fremhæver Dahler-Larsen tre forhold i den danske skoletradition, som er typisk grundtvigske: mundtligheden (og herunder modstanden imod skriftligheden), fallesskabet og folkeligheden. Disse tre forhold, siger Dahler-Larsen, er en del af det, Ove Korsgaard betegner som den lodrette oplysningstradition, og det er især denne tradition, som er miseren bag det danske skolevæsens mange problemer i dag: "Den lodrette og folkelige oplysningstradition var med til at skabe problemerne (...) Grundtvig var med til at skabe den holdningsdannelse, der gjorde fornuftsbaserede løsninger umulige" (Undervisningsministeriet 2007, 36). I sammenhængen er det tydeligt underforstået, at der er tale om det danske skolesystem.

Dahler-Larsen læser imidlertid Korsgaard forkert. Fejlagtigt knytter han Grundtvig og det såkaldt "lodrette oplysningsbegreb” sammen, hvad Korsgaard netop ikke gør. Grundtvig var stærk modstander af, at oplysningen i skolen skulle komme oppefra - altså at religionen og troen på, Gud skulle være styrende for skolens virksomhed. En række steder og ikke mindst i skriftet fra 1836, Er Troen virkelig en Skolesag, tager han tværtimod skarpt afstand fra at blande skoleoplysning sammen med trosoplæring. F.eks. skriver han, at det er hans opfattelse:

at Troen, Gud skee Lov! slet ingen Skole-Sag er, men at den hele ReligjonsUnderviisning i Skolerne, som vi giennem Aarhundreder har plaget os 
selv og Børnene med, var en stor Vildfarelse, som vi skal glæde os over, den herskende Forvirring endelig har nødt os til at indsee (US VIII, 108).

I modsætning hertil antager Dahler-Larsen altså, at Grundtvig har en særlig - oven i købet negativ - betydning for den danske folkeskole, uden at han har sat sig ind i Grundtvigs tankegang.

Vurderingen af Grundtvig som en positiv eller negativ indflydelsesperson ligger også bag udsagnet "i Grundtvigs fædreland". Udtrykket bruges ofte $\mathrm{i}$ en argumentation til forsvar for eller modstand imod et bestemt sagsforhold, og det er sjældent efterfulgt af en forklaring på, hvad der menes med "i Grundtvigs fædreland”. Udtrykket fremsættes som en underforstået rigtig måde at gøre eller tænke om bestemte forhold på i Danmark og anvendes således ofte i sin underforståethed og manglende eksplicitering til at fremme afsenderens egen forståelse og tillige inkludere modtagerens og dermed afmontere dennes eventuelle anden forståelse.

Et eksempel på en sådan argumentation finder man i professor Niels Egelunds kronik i Politiken den 26.12.2011. Efter at have beskrevet og anprist det kinesiske undervisningssystem og påpeget, hvordan det danske skolesystem ville vinde ved at lægge sig mere op ad det kinesiske, slutter han polemisk kronikken med følgende ord:

Konklusionen er, at selv vi i Grundtvigs fædreland kan indføre lidt kinesisk undervisningskultur, hvis vi altså vil, og hvis vi arbejder sammen med forældrene om det, og jeg er helt sikker på, at vi vil opleve, at såvel elever som lærere bliver gladere og mere tilfredse i deres dagligdag - og at vi faktisk kan nærme os den skole i verdensklasse, som danskerne fortjener.

Af kronikkens sammenhæng fremgår det, at Egelund mener, at det positive ved det kinesiske skolesystem er, at eleverne i Kina er mere flittige, fagligt orienterede og disciplinerede. Den måde, hvorpå Egelund her anvender udtrykket 'i Grundtvigs fædreland', implicerer altså, at Grundtvig kan være en forhindring for forandring til det bedre i et skolesystem som det (selvtilfredse) danske, fordi den grundtvigske påvirkning har skabt en faglig og disciplinær skole, der er for slap, men udsagnet angiver samtidig, 
at Egelund mener, Grundtvigs skoletanker $m a ̊$ have haft afgørende indflydelse på det danske skolesystem.

Ingen steder hos Grundtvig kan man formentlig dokumentere en sådan holdning til skolearbejde, som Egelund mener at finde i det danske skolesystem. Der er altså igen tale om en opfattelse af Grundtvigs indflydelse på skolesystemet, som bygger på en bestemt forestilling - eller hvad der i det følgende vil blive kaldt en myte. Det tyder på, at der, hvad angår Grundtvigs indflydelse på skolen, både blandt videnskabsfolk og i bred almindelighed eksisterer en myte om, at Grundtvig har haft indflydelse på folkeskolen.

Med udgangspunkt i denne tese vil det i det følgende blive undersøgt, hvad der mere præcist er mytens indhold, og hvad der er baggrunden for mytens tilblivelse og indhold. Spørgsmålene besvares gennem en målrettet interviewundersøgelse med særligt udvalgte, relevante personer og med fokus på, hvordan de opfatter Grundtvigs indflydelse i folkeskolen. Opfattelserne udgør til sammen myten om Grundtvigs indflydelse, og interviewene bliver underlagt en analyse med henblik på afdækningen af denne mytes indhold og funktion.

\section{Overvejelser over brugen af mytebegrebet}

I det følgende skal der kort redegøres for etableringen af de centrale analysekategorier, som vil blive anvendt i analysen og myteafdækningen. Mytebegrebet er oprindeligt knyttet til en religiøs diskurs og betyder i den sammenhæng gudesagn, men begrebet anvendes nu også i overført betydning, ${ }^{1}$ hvor det dækker over forskellige opfattelser - det kan være en opdigtet fortælling, der mangler virkelighedsgrundlag, en løgnehistorie, en karakteristik af særligt fremtrædende personligheder - f.eks. er det anvendt om den tidligere statsminister Th. Stauning. Det bruges i øvrigt også om en særlig litterær form, eksempelvis hos Johannes V. Jensen. I daglig tale er mytebegrebet almindeligvis forbundet med ord som løs snak, løgn eller noget opdigtet og er i den forstand udtryk for noget negativt.

\footnotetext{
${ }^{1}$ En spændende gennemgang af mytens udviklingshistorie kan findes i Olof Sundqvist og Anna Lydia Svalastog (red.) Myter og myteteorier (1997).
} 
I nærværende sammenhæng bliver mytebegrebet også anvendt i overført betydning og i den forstålse, at myte betegner en forestilling eller en opfattelse, som ikke har hold i noget virkelighedsforhold, dvs. ikke nødvendigvis er sandhed. Samtidig har myten også virkelighedskarakter, fordi den er emotionsmotiverende og handlingsanvisende i større eller mindre grad - dvs. får en faktisk funktion. Med baggrund i den forståelse vil mytebegrebet blive anskuet ud fra to overordnede perspektiver: myten set i et "sandhedsperspektiv" og myten set i et "funktionsperspektiv".

\subsection{Myten i et "sandhedsperspektiv"}

Sandhed skal her forstås i positivistisk forstand - dvs. i dimensionen sand/ falsk.

I følgende eksempel, som er en pressemeddelelse fra Ritzau, er der f.eks. sket en fuldstændig ækvivalering mellem myte og en usand historie:

Offensiv mod myter om Danmark!

Det er forbudt at gå med tørklæde i Danmark, og muslimer har ikke samme rettigheder som ikke-muslimer. Myter som disse har verseret i flere arabiske medier efter muhammedkrisen, og dem vil Udenrigsministeriet nu komme til livs, fortæller DR Nyheder (Pressemeddelelse fra Ritzaus Bureau 24.10.2008).

En absolut usand historie betegnes altså her med ordet myte. Det er alene det, at udsagnet er løgn, der gør det til en myte. Det er en meget bastant forenkling af mytebegrebet, der er tale om. I historievidenskabssammenhæng, vil man lidt mindre bombastisk sige, at myten er en forestilling om verden, som kildestudier kan påvise ikke passer (se f.eks. Niels Arne Sørensen 2005). Eller i mere afsvækket form: en forestilling om verden, som ikke kan eftervises gennem kildestudier. ${ }^{2}$

2 Et tydeligt eksempel på denne kildekritiske opfattelse kan også ses i det lille hæfte Myte og realitet i danmarkshistorien (ved Jørgen Mentz og Søren Mørch 1975)). Til brug for historieundervisningen i gymnasiet præsenteres forskellige kilder med henblik på, at eleverne gennem kildestudier skal afgøre om udvalgte hændelser i danmarkshistorien er myte eller virkelighed. Myte er altså i Mentz og Mørchs forståelse ikke virkelighed. 
Et andet eksempel på et sådant 'sandhedsperspektiv' på myten, hvor både det usande og det negative er indlejret i mytebegrebet, er hjemmesiden www.danmarkshistorien.dk fra Aarhus Universitet, hvor der præsenteres et såkaldt mytedraber-varksted. Her bliver det f.eks. afdækket, at det ikke var Dalgas, men en anden, der er ophavsmand til udtrykket: "Hvad udad tabes, skal indad vindes". Karakteristisk for denne myteforståelse er, at det ikke angives, hvorfor det er interessant at få afdækket denne 'myte'. Alene afdækningen af, om det er 'sandt' eller 'falsk', er i den sammenhæng afgørende. Hvilken betydning, det har haft, at udsagnet har været knyttet til Dalgas, undersøges ikke, fordi mytens funktion for 'mytedræberen' er uinteressant. Hensigten er, at uvæsenet bliver afsløret og udryddet! Man kunne i forbindelse med "mytedræber-værkstedet" drøfte, hvorvidt idealet om, at skrælle usandheden væk for at opnå den rene, sande virkelighed, er holdbart. Således ville historikere af socialkonstruktivistisk observans tage afstand fra idealet og erklære det for uopnåeligt - ja, måske ligefrem for en myte!

Til trods for denne problematisering kan det alligevel være interessant at arbejde med myten i et 'sandhedsperspektiv' af to grunde:

1) Af heuristiske grunde - dvs. ud fra et ønske om at få ny viden om et bestemt forhold eller fænomen - f.eks. om Grundtvigs indflydelse på udviklingen af folkeskolen. Vi ved meget om Grundtvigs tanker som grundlag for de frie børneskoler (friskoler og efterskoler), men ikke om hans indflydelse på folkeskolen. Bag denne begrundelse ligger altså den forståelse, at myten, som begrebet forstås her, altid i større eller mindre grad har en forankring i et virkelighedsfænomen i nutiden eller i historien.

2) Af ideologikritiske grunde - dvs. ud fra ønsket om at afdække, om der bag ved et eksplicit, bestemt udsagn om samfundet ligger en ikke-ekspliciteret ideel forståelse af verden, som af forskellige grunde ikke kommer til udtryk. Det drejer sig f.eks. om, hvorvidt et udsagn om Grundtvigs indflydelse i folkeskolen er faktuelt begrundet, eller om udsagnet har ideologisk baggrund, og hvilken funktion udsagnet i givet fald så har. Myten vil med andre ord altid være et konglomerat af et virkelighedsgrundlag (af noget som i positivistisk forstand vil være sandt) og en ideologisk funktion. Når mytebegrebet derfor i nedenstånde anvendes i undersøgelsen af Grundtvigs indflydelse i folkeskolen, er det i denne dobbelte forståelse, hvor påstanden om hans indflydelse både har en faktuel og en ideologisk baggrund. 


\subsection{Myten i et "funktionsperspektiv"}

Myten repræsenterer altså en forståelse af verden (dvs. er en bevidsthedsstruktur), som har rod i en faktisk virkelighed, og som samtidig har en idébaseret menings- og betydningsskabende funktion i forhold til vores iagttagelser og oplevelser. Dette gør det nødvendigt også at betragte myten i et funktionsperspektiv: Myten skal altid bruges til noget af nogle!

Flere historieforskere har arbejdet med forholdet mellem historie og myte, og mange vil hævde, at der kun er kort mellem begreberne. Lektor i historie Jens Aage Poulsen hævder eksempelvis i en artikel, at det er svært at skelne mellem historie og myte - eller, som han siger, mellem den levede historie og den fortalte historie (herunder også den videnskabeligt funderede fremstilling af historien). Han henviser til den amerikanske historiker William H. McNiell, som anvender begrebet mythistory for at angive vanskeligheden (Poulsen 2010). Med en sådan historieopfattelse bliver hensigten for historikeren ikke at søge en positivistisk sandhed bag en bestemt myte, men at efterspørge mytens funktion og virkning, aktuelt og i historien. Dette mytebegreb tager udgangspunkt i en socialkonstruktivistisk historieforståelse, som hævder, at forskellen mellem den måde, hvorpå vi fortolker og sprogliggør vores sansemæssige perceptioner og vores etablering af myten, er meget lille. ${ }^{3}$

Myterne vil som sagt noget, og dette noget skal afdækkes. Selve myteafdækningen bliver et første og nødvendigt skridt af en undersøgelse af mytens virkningshistorie. Det er samme tankegang, Jens Aage Poulsen giver udtryk for, når han siger, at det er: "relevant at forsøge at afdække, hvordan myten er opstået, hvem der har brugt den, med hvilket sigte og med hvilket resultat. Man kan også sige, at den type myter er virkningshistorisk interessante" (Poulsen 2010, 93).

Med begrebet virkningshistorie lanceres et omdiskuteret begreb. I nærværende artikel vil det blive defineret således: En tanknings eller en persons virkningshistorie er beskrivelsen af denne tonknings eller persons fortolknings-, receptions- og/eller brugshistorie. I relation til mytebegrebet er virkningshistorien altså svar på spørgsmålene om, hvordan er myten opstået, hvem

${ }^{3}$ Ikke mindst den filosofiske hermeneutik har i sit opgør med bl.a. naturvidenskaben arbejdet med spørgsmålet om, om mennesket kan forstå verden umiddelbart uden at fortolke den, altså om der kan etableres en viden baseret på en ren og ikke fortolket perception. 
der har anvendt den, med hvilket sigte og med hvilket resultat. Det er dog ikke ambitionen i denne artikel at undersøge og beskrive, hvordan myten om Grundtvigs virkningshistorie er blevet til og har udviklet sig. Interessen er først og fremmest at få afdækket denne mytes indhold og funktion i forhold til nogle konkrete, interviewede myteskabere.

\subsection{Myteafdakning}

I arbejdet med afdækningen af mytens virkelighedsgrundlag og dens ideologiske funktion er det vigtigt at gøre sig klart, at myten altid er en bevidsthedskonstruktion. Som sådan bliver den en del af et folkeligt normativ, dvs. en del af det, der - som oftest ubevidst - er bestemmende for menneskers virkelighedsopfattelse og handlinger i en given kultur, hvad enten de er sproglige eller konkrete. I sin bog om mytologier siger Roland Barthes (Barthes 1998), at myter er "naturliggjort" historie, og understreger hermed, at en bestemt betragtningsmåde af samfundsmæssige fænomener kan blive gjort til ikke blot det almindelige, men til det normale og dermed til noget normativt. Faren ved en sådan "falsk selvfolgelighed" (Barthes 1998, 24) er undertrykkelse af anderledes tænkende og hegemoni af særligt begunstigede opfattelser. Derfor er myter iflg. Barthes 'falsk bevidsthed', som skal afdækkes gennem ideologikritik. Barthes hævder, at den form for falsk bevidsthed alene er et borgerligt fænomen, som venstrefløjen ikke ligger under for.

Så entydigt betragtes det ikke af den norske professor og socialantropo$\log$ Thomas Hylland Eriksen. Ifølge Eriksen er det, at mennesker etablerer myter, et almenmenneskeligt træk. "De [myterne] kan derfor ikke avfeies som falsk bevissthet; de må forstås som et fundamentalt uttrykk for den menneskelige væremåte.” (Eriksen 1996, 19). Endvidere hævder han, at myter er livsnødvendige for mennesket, fordi de fortolker og tildeler fortiden og nutiden helhed og mening. Mennesket "lever ikke av sannhet alene, men også af mening (...) Selve vår menneskelighet er knyttet til meningsfyldte historier" (Eriksen 1996, 108). ${ }^{4}$ For Eriksen har myternes

\footnotetext{
${ }^{4}$ En uddybning af opfattelsen af mytedannelse som et grundlæggende træk ved det at være menneske kan man finde i bogen Myte og eksistens (1992), som er skrevet af den amerikanske psykoanalytiker Rollo May. Bogen igennem argumenterer hun for, at "Skabelse af myter er afgørende for vor sjælelige sundhed" (May 1992, 13).
} 
fortolkende kraft en iboende dobbelthed. På den ene side kan de ved deres identitetsskabende funktion føre til undertrykkelse af folk, der tænker anderledes end flertallet. Et grelt eksempel er, når national mytologi legitimerer folkemord. På den anden side er myter afgørende nødvendige for opbygningen af et samfund med demokrati og forståelse for og accept af anderledeshed: "Den som vender sig kategorisk mot enhver mytedannelse, vender sig derfor samtidig ikke bare mot demokratiet, men mot en grunnleggende side ved det å være menneske” (Eriksen 1996, 109).

Eriksens arbejde med myten har en række bemærkelsesværdige og ikke tilfældige ligheder med hermeneutikkens ${ }^{5}$ arbejde med at rehabilitere begrebet fordom. Også dette begreb har i sin hverdagsbrug, hvor det almindeligvis indgår $\mathrm{i}$ en moralsk diskurs, ligesom mytebegrebet en aura af noget negativt knyttet til sig. Den filosofiske hermeneutik ønsker i modsætning hertil at tildele begrebet fordom en epistemologisk og positiv betydning. Teologen H.C. Wind forklarer det således:

For-dommen er ikke selve dommen, den endegyldige mening, men er betingelsen for at det overhovedet kan komme til en mening. Som det gælder, at uden for-ventning kan ingen oplevelse eller erfaring bringes til veje, uden interesse kan ingen indlæring finde sted, således er fordommen den samlede betegnelse for, at mennesket som historisk væsen er forbundet med den verden, det lever i. For-domme er formidlingen mellem mennesket og dets verden (Wind 1987, 58 ff.).

I forbindelse med myter er denne indsigt overordentlig relevant, da fordomme ofte opstår af myter og fordi myterne ofte bliver tilført indhold via fordomme. Fordomme og myter, i den betydning, som hermed er angivet, er ligeledes beslægtede, idet begge begreber vil beskrive vilkår og særtræk for menneskelig erkendelse og udvikling, og begge har en bestemmende betydning for menneskets måde at tænke og handle på. I almindelig hverdagstale ligger begreberne da også i deres forståelse og anvendelse meget tæt på hinanden og kan endda optræde som ækvivalerende begreber.

${ }_{5}^{5}$ Det er især H.-G. Gadamer (og dermed den filosofiske hermeneutik), der i bogen "Sandhed og metode" (1986) provokerende har sat lighedstegn mellem fordom og forforståelse. 
En pointe for Eriksen er, at myter og fortællinger som bevidsthedsfanomener skaber handling og forandring i menneskers liv - det individuelle liv såvel som det fælles. Det lægger sig op ad den grundtvigske forståelse, at 'ordet skaber, hvad det nævner'. For Grundtvig var ordets, fortællingens eller mytens kraft som grundlag for udvikling af både individer og fællesskaber (f.eks. samfund, folk og skoler) helt fundamentalt. I den forstand kan Grundtvig sammenlignes med nutidens socialkonstruktivister. De er fælles om det synspunkt, at mennesket gennem fortællingen skaber en bevidsthed om virkeligheden omkring sig og dermed også om sig selv og fællesskabet. En ændring af virkeligheden kan derfor også kun ske gennem en ny fortælling. I skriftet Om borgerlig Dannelse fra 1834 angiver Grundtvig f.eks., at almuen for at ændre på sin situation må få en ny fortalling om sig selv. Han siger det på sin måde i skriftet ved at hævde, at en grundlæggende ændring af almuens vilkår kræver, at almuen "maatte ... først ved en højere Dannelse være aandelig traadt ud af deres Sphære og var da ikke længere Almue”. (GSkv I, 259).

I sin disputats Den fortallende skole - muligheder i skoleudvikling har professor Mads Hermansen ligeledes gjort rede for, hvordan fortællinger (i Eriksens forstand myter) kan bruges i en skoleudviklingsproces og dermed også i en definitionsproces - altså den proces, hvor en bestemt konkret virkelighed etableres (Hermansen 2001). Den, der bevidst eller ubevidst styrer fortællingen eller myten, har definitionsretten. Det er således langt fra ligegyldigt, hvad fortællingens eller mytens indhold er, og hvem der etablerer den. Netop dette forhold har været styrende for udvælgelsen af interviewpersonerne her i undersøgelsen.

\section{Interviewundersøgelsen}

\subsection{Hvem blev interviewet og hvorfor?}

Der er foretaget interview med 20 forskellige mennesker. Af nedenstående oversigt vil det fremgå, at der skulle have været 21 personer, så der var tre $\mathrm{i}$ hver kategori. Desværre meldte en fra i sidste øjeblik. Interviewene er båndede og foregik i stor udstrækning på interviewpersonernes arbejdskontorer eller i deres hjem. Det var ikke ambitionen at afdække en 'Grundtvigfolkeskole-myte' blandt mennesker i almindelighed, men netop kun hos 
personer, hvis myteforestilling har definerende betydning i skolediskursen og dermed også i skolevirkeligheden. Derfor er undersøgelsespopulation så begrænset, som den er. Til gengæld blev valget af personer styret af deres nuværende eller tidligere position som centrale og betydende personer $\mathrm{i}$ den danske skolediskurs. Den konkrete udvælgelse skete ud fra både nogle generelle og nogle specifikke kriterier.

De generelle kriterier for udvælgelsen, som begge skulle opfyldes, var, at det skulle være:

1. Personer, der havde et kendskab til folkeskolen, konkret, som arbejdsplads eller som samfundsinstitution.

2. Personer, der havde en begrundet holdning til folkeskolen.

Personerne skulle endvidere opfylde et eller flere af følgende specifikke kriterier:

1. At de gennem deres arbejde har/har haft en indflydelse på meningsdannelsen i snævre eller brede relevante faglige kredse i samfundet.

2. At de gennem deres arbejde har/har haft en indflydelse på lovgivningen i relation til folkeskolen.

3. At de gennem deres arbejde har et kendskab til den danske skolehistorie.

4. At de gennem deres arbejde har et grundigt kendskab til Grundtvigs tanker og tankernes udfoldelse i de grundtvigske kredse.

Ud over disse kriterier var det vigtigt at vælge personer, som i deres arbejde nød almindelig anerkendelse som seriøst arbejdende fagpersoner. Dette førte til interview med:

- 3 tidligere undervisningsministre

- 2 tidligere ledende embedsmænd i Undervisningsministeriet (skulle have været 3, men én meldte fra i sidste øjeblik)

- 3 skolehistorikere (dvs. forskere, som er kendt som og opfatter sig selv som skolehistorikere)

- 3 skolefolk (centralt placeret i skoleverdenen) 
- 3 Grundtvig-forskere (dvs. forskere, som både er kendt som og opfatter sig selv som Grundtvig-forskere)

- 3 samfundsanalytikere (dvs. forskere, hvis virke i offentligheden især forbindes med analyse af forskellige overordnede samfundsforhold)

- 3 pædagogiske forskere (dvs. forskere, som arbejder med generelle forhold vedrørende pædagogik og undervisning).

Karakteriseringen af de forskellige interviewpersoner skal forstås på den måde, at den knytter sig til personens hovedfunktion i forhold til nærværende undersøgelses sammenhæng. En Grundtvig-forsker vil således f.eks. ofte inddrage skolehistorie og samfundsanalyse i sit arbejde, men i undersøgelsen har det været pågældendes Grundtvig-forskning, der var afgørende for udvælgelsen.

\subsection{Interviewformen}

Interviewene blev gennemført som strukturerede interview $i$ samtaleform. Spørgsmålene i samtalen skulle sikre, at fem centrale spørgsmål i relation til den enkelte person ville kunne besvares efter interviewet:

1. Hvor stort er dit kendskab til Grundtvigs pædagogiske tænkning?

2. Mener du, Grundtvigs pædagogiske tænkning har haft indflydelse på folkeskolens udvikling?

Hvis svaret på dette spørgsmål er ja - da også:

3. Er denne indflydelse efter din mening positiv eller negativ?

4. Hvor og hvordan i folkeskolens virksomhed ser du indflydelsen fra Grundtvigs pædagogiske tænkning?

5. Hvordan er indflydelsesvejen fra Grundtvigs pædagogiske tænkning til indflydelsen i folkeskolen?

Samtalerne blev optaget på bånd, udskrevet og gemt. Derefter blev de analyseret med baggrund i de fem spørgsmål. 


\subsection{Interviewenes indholdsramme}

Der er et klart definitorisk problem med begrebet "Grundtvigs padagogiske tonkning", idet det både kan henvise:

1. Direkte til en tankning, som Grundtvig selv har beskrevet i de værker, hvor han behandler pædagogik, undervisning og skole. Det vil sige en tænkning, som principielt kan beskrives og defineres ud fra Grundtvigs tekster og derfor benævnes: Grundtvigs padagogiske tankning. ${ }^{6}$

2. Til en tænkning, som blev baggrunden for en praksis, der blev udfoldet af en række skolefolk og andre, som kaldte sig grundtvigske. Mere præcist kunne man benævne den: en grundtvigsk padagogisk tonkning.

Det er vanskeligt, når arbejdet med Grundtvigs skrifter skal udmønte sig i en entydig beskrivelse af hans tankegang på et særligt område. Det kan ofte skyldes, at han har ment og skrevet forskelligt til forskellige tider om det samme emne, og at han tit udtrykker sig i vanskeligt fortolkelige udsagn. Med hensyn til Grundtvigs tanker om skolen er der tillige det problem, at han faktisk kun ganske få steder forholder sig direkte til børneundervisning. Hans livslange oplysningsærinde var i særlig grad rettet mod voksenoplysning.

Når det drejer sig om en grundtvigsk pædagogisk tænkning hos de mennesker, som udfoldede hans tanker og omsatte dem til f.eks. børneundervisning, opstår der ligeledes det problem, at man har fortolket Grundtvig forskelligt både inden for bestemte perioder og op igennem historien. Man kan derfor stille spørgsmålet: Hvad er det, der spørges om, når interviewpersonerne er blevet spurgt om deres kendskab til 'Grundtvigs pædagogiske tænkning'?

Her blev der over for interviewpersonerne bevidst ikke redegjort for en bestemt opfattelse af Grundtvigs pædagogiske tænkning og heller ikke angivet, at spørgsmålet kunne opfattes på flere forskellige måder. Det har været op til den enkelte interviewperson bevidst eller ubevidst at tolke begrebet 'Grundtvigs pædagogiske tænkning'. Da det drejede sig om at

\footnotetext{
${ }^{6}$ Når jeg skriver 'principielt', er det, fordi receptionen af Grundtvigs tanker altid vil være bundet af tid og sted og person (og uenigheden om fortolkningen har været og er da også omfattende), men at der foreligger en faktisk tekst, som ideelt set vil kunne fortolkes 'rigtigt' - dvs. som Grundtvig har ment den, da han skrev den.
} 
afdække interviewpersonens myte om Grundtvigs indflydelse, var det netop ikke vigtigt at få klarlagt pågældendes forståelse af hans pædagogiske tænkning. I samtalen måtte der således gives plads for udsagn om Grundtvigs tænkning, som intervieweren fandt decideret forkerte, uden at disse blev modsagt. Når der i det følgende skrives 'Grundtvigs indflydelse', henvises der altså til, at indflydelsen enten kan være sket direkte, dvs. i en lige linje fra Grundtvigs egne udsagn til en folkeskolepraksis, eller at indflydelsen kan være foregået indirekte, dvs. gennem de mennesker, der forstår eller betegner sig som grundtvigske skolefolk.

\subsection{Interviewpersonens kendskab til og opfattelse af Grundtvigs padagogiske tonkning}

Nedenstående skalaopstilling over interviewpersonernes kendskab til Grundtvig er fremkommet ved, at personen enten selv har udtrykt sig om sit kendskab til Grundtvig, eller ved, at jeg har tolket omfanget af den enkeltes kendskab. Det er ligeledes også alene mig, der ud fra min fornemmelse har bestemt værdien af skalatrinene og de enkelte personers placering på skalaen. Det er således en klar subjektiv-orienteret vurderingsskala og opstilling. Der opereres med et kontinuum af kendskab fra intet til omfattende. Med 'kendskab' menes en systematisk viden, der baserer sig på studier af Grundtvigs skrifter enten via egne kildestudier eller gennem læsning af sekundærlitteratur. Det drejer sig altså om viden, som ligger ud over den viden om Grundtvig, man evt. har fået gennem skolen og gymnasiet eller gennem avislæsning og lignende.

På en skala fra 0 til 4, hvor 0 er intet kendskab til Grundtvigs pædagogiske tænkning, og 4 er stort og omfattende kendskab, fordeler interviewpersonerne sig således:

$0=4$ personer

$1=2$ personer

$2=5$ personer

$3=5$ personer

$4=4$ personer 
Det vil sige, at 11 personer (skalatrin 0, 1 og 2) har intet eller et begrænset kendskab til Grundtvigs pædagogiske tænkning, og 9 (skalatrin 3 og 4) har en del eller stort kendskab til tænkningen. Alle 20 interviewede mener, at Grundtvigs tænkning har og har haft indflydelse på folkeskolens udvikling. Heraf mener 17, at indflydelsen har været stor, mens 3 mener, at indflydelsen har været begrenset. 15 personer opfatter Grundtvigs indflydelse som positiv, 2 mener indflydelsen har været negativ, 1 person mener, at indflydelsen har været både-og, mens 2 personer ikke forholder sig til dimensionen positiv/negativ (men altså alligevel hævder, at indflydelser er der).

Blandt de 15 personer, der siger, at indflydelsen har været positiv, har 6 intet eller kun begrænset kendskab til Grundtvigs tænkning, mens 9 har en del eller stort kendskab. De 2, som udtrykker, at Grundtvigs indflydelse er negativ, er begge personer med intet eller lille kendskab til Grundtvigs tanker, og den person, som siger både-og, har heller ikke kendskab til Grundtvigs tænkning. I interviewgruppen er der altså 11 personer, som udtaler sig om Grundtvigs indflydelse på folkeskolen (og 9 af dem kvalificerer endda indflydelsen) uden at have konkret kendskab til Grundtvigs pædagogiske tanker eller hans tænkning i det hele taget. Der er altså i høj grad tale om en række opfattelser, som ikke er begrundet i et faktuelt kendskab, men som må have sin rod et andet sted. Dette forhold vil blive taget op senere, men det er den manglende sammenhæng mellem det klare udsagn om Grundtvigs indflydelse og det sparsomme kendskab til Grundtvig, der blev afgørende for, at interviewpersonernes opfattelse i analysen blev indfældet $\mathrm{i}$ en mytediskurs.

\subsection{Mytens indhold}

For at bestemme mytens indhold mere præcist blev samtlige udsagn om Grundtvigs indflydelse oplistet. Udsagnene blev herefter samordnet til 5 indflydelsesområder. Denne inddeling kan naturligvis diskuteres. Hensigten bag har dels været ønsket om en forenkling af analysearbejdet, dels et forsøg på at opdele efter kategorier, der i andre sammenhænge anvendes, når der forskes i skole. Resultatet blev på den baggrund følgende fem kategorier: 
1. Skolens kultur

2. Skolens læringsmetoder

3. Skolen som dannelsesinstitution

4. Skolens strukturelle forhold

5. Skolens faglige indhold

Nedenfor er nævnt de centrale ord i personernes udsagn om de forskellige kategorier. Desuden er der foretaget en prioriteret kategoriopstilling efter antal gange udsagnene er nævnt i interviewene. Det er således forudsat, at der er en ligefrem proportional sammenhæng mellem antal gange, et udsagn forekommer, og den vagt, interviewpersonen lægger på indflydelsesområdets betydning. Denne forudsætning kan naturligvis diskuteres, og den er alene et udslag af ønsket om at kunne kvantificere udsagn, som i øvrigt er kvalitative. Det diskutable i fremgangsmåden er der dog forsøgt taget højde for gennem en klar redegørelsen for fremgangsmåden og ved for læseren at fremlægge samtlige interviewudsagn om de områder, interviewpersonerne mener, Grundtvigs tænkning har haft indflydelse på.

\section{Skolens kultur (45 udsagn)}

Under begrebet 'skolens kultur' er samlet udsagn, som ved rører forskellige opfattelser af eleverne og lærerne såvel som den måde, relationen mellem dem manifesterer sig på i hverdagen. Udsagnene deler sig i to grupper. Det drejer sig dels om udsagn, der opfatter den grundtvigske tankegangs indflydelse som positiv, dels om udsagn, som opfatter indflydelsen som negativ, når det drejer sig om skolens kultur.

Udsagn, som hæftes på en positiv indflydelse, er: det hele menneske, menneskeopfattelsen, mild disciplin, vekselvirkning mellem personer, dialog, lareren opfattes som en person (snarere end eller $i$ tillag til at vare en faglig professionel), ansvar hos eleven, klasselarersystemet, larerens metodefrihed, ligevardighed, det frie ord, elevindflydelse, traditionsdyrkelse (i alt 39 udsagn).

Udsagn, som hæftes på en negativ indflydelse, er: antiautoritert og slapt, larerens afståelse fra rationalitet og forskningsindstilling, det lodrette oplysningsbegreb, fallesskab kommer for faglighed, antiprofessions-indstilling hos lererne, antiintellektualisme (i alt 6 udsagn). 


\section{Skolens læringsmetoder (31 udsagn)}

Med læringsmetoder menes der måder, hvorpå skolen etablerer og definerer sit læringsmiljø med henblik på den største mulighed for læring hos eleverne. Interviewpersonernes udsagn om læringsmetoder, hvori den grundtvigske tankegangs indflydelse manifesterer sig, drejer sig om: (faktisk) brug af viden, praksisnar undervisning, fortalling, mundtlighed, ligestilling af haind og and, nedprioritering af eksamen og karakterer, lare af lyst, brug af erfaring og sanser, organisk syn på laring, antiautoriter undervisning.

\section{Skolen som dannelsesinstitution (26 udsagn)}

Med skolen som dannelsesinstitution menes der den påvirkningsopgave, som skolen af lovgivningen og forældrene tillægges ud over den skolefaglige opgave at lære eleverne bestemte skolefag. Dannelsesopgaven kan være rettet såvel mod eleverne som personer som kommende samfundsborgere. Interviewpersonernes udsagn om forestillingen om Grundtvigs indflydelse på dette område kan listes således: at understøtte elevernes livsduelighed, at gøre eleverne kritiske, selvstendige, demokratisk indstillede, at skabe skolens egenvardi, at skabe historiebevidsthed, at skolen er opdragende, kanon = kulturbevidsthed, nationalfolelse, fallesskab, lighed og almenvellets oplysning.

4. Skolens strukturelle forhold (20 udsagn)

Skolens strukturelle forhold skal i denne sammenhæng alene forstås som de lovgivningsmæssige strukturforhold, som skolen er underlagt. Udsagnene fra interviewpersonerne om forhold, der betegnes som resultat af grundtvigsk indflydelse vedrørende de strukturelle forhold kan samles i følgende kategorier: gratis skolegang, enhedsskole, eleverne samlet $i$ deres klasser $i$ mange air, decentral styring af skolen, undervisningspligt, lovpligtigt forcldresamarbejde.

5. Skolens faglige indhold (10 udsagn)

Overskriften kategoriserer udsagn om, at skolen har fag, der skal undervises i. Det drejer sig dels om, hvilke fag der er tale om, dels om det indhold, disse fag skal have, og endelig om fagenes omfang. Nogle af de intervie- 
wede mener, at indflydelsen fra Grundtvigs tanker har givet sig udtryk i fagene: sang, historie, geografi, modersmålldansk, bibelhistorie. I alle de 10 tilfælde, hvor tilstedeværelsen af visse fag udpeges som et resultat at grundtvigsk tankegang, er det interviewpersonernes opfattelse, at der er en klar sammenhæng mellem disse fag og formidlingen af den danske kultur.

\section{Systematisering}

Ud over disse indflydelsesområder fremhæves det af og til af interviewpersonerne, at vores generelle forestilling om skolen som læringsinstitution også er under indflydelse af grundtvigsk tankegang. Især trækkes Grundtvigs begreb "den sorte skole" frem som en fælles accepteret og anvendt 'modsætningsindikator', altså som et afgørende billede på, hvad det er for en skole, der ikke ønskes.

En nærmere analyse af ovenstående 5 indflydelsesområder viser, at udsagnene fordeler sig således i forhold til de interviewedes hovedkendetegn: ${ }^{7}$

$\begin{array}{lrrrrrrr} & \text { SH } & \text { EM } & \text { PF } & \text { GF } & \text { SkF } & \text { MI } & \text { SF } \\ \text { 1. Kultur } & 3 & 1 & 12 & 6 & 9 & 8 & 6 \\ \quad \text { positivt: } & 2 & 1 & 7 & 6 & 8 & 8 & 6 \\ \text { negativt: } & 0 & 0 & 5 & 0 & 1 & 0 & 0 \\ \text { 2. Metode } & 8 & 0 & 2 & 9 & 4 & 4 & 4 \\ \text { 3. Dannelse } & 3 & 2 & 4 & 3 & 10 & 1 & 3 \\ \text { 4. Struktur } & 7 & 4 & 3 & 0 & 2 & 3 & 2 \\ \text { 5. Fag } & 1 & 0 & 0 & 6 & 0 & 2 & 1\end{array}$

På den baggrund kan der nu opstilles en tabel for de indflydelsesområder, som af de forskellige persontyper bliver stærkest fremhævet:

\footnotetext{
${ }^{7}$ Forkortelser: $\mathrm{SH}=$ skolehistorikere, $\mathrm{EM}=$ embedsmænd, $\mathrm{PF}=$ pædagogiske forskere, $\mathrm{GF}=$ Grundtvig-forskere, $\mathrm{SkF}=$ skolefolk, $\mathrm{MI}=$ ministre, $\mathrm{SF}=$ samfundsforskere.
} 
Kultur Metode Dannelse Struktur Faglighed

Skolehistorikere $38 \%$

$(33 \%)$

Embedsmænd

(29\%) $\quad 57 \%$

Pædagogiske forskere

$27 \%$

$(19 \%)$

Grundtvigforskere

(25\%) $38 \%$

Skolefolk

$(36 \%)$

$40 \%$

Ministre

$44 \%$

$(22 \%)$

Samfundsforskere

$37 \%$

$(25 \%)$

(Procenttallene i parentes refererer til persontypens nasthøjeste prioritering)

Det er bemærkelsesværdigt, at skolens dannelsesopgave af praktikerne er udpeget som det mest fremtrædende grundtvigske træk i folkeskolen. Desuden er det påfaldende, at ingen fremhæver indflydelsen på fagligheden som det vigtigste. De relativt fà gange, fagligheden nævnes, er det langt overvejende i udsagn fra grundtvigforskere. Det er også værd at lægge mærke til, at de folk, der går historisk til værks (skolehistorikere og grundtvigforskere), fremhæver metoden som det vigtigste indflydelsesområde - måske fordi de sammenligner den nuværende skole med skolen, som den var engang.

Billedet af den grundtvigske indflydelse i folkeskolen hos de 20 personer, der er interviewet, kan på hele denne baggrund sammenfattes $\mathrm{i}$ følgende prioriterede rækkefølge:

1. Grundtvigs indflydelse i folkeskolen har først og fremmest bestået i en påvirkning af skolens hverdagskultur. Dette kommer især til udtryk ved:

- måden, hvorpå elev og lærer og eleverne indbyrdes omgås hinanden (den kan være vurderet dels positivt: præget af ligeværdighed, respekt og dialog, dels negativt: præget af en slap disciplin).

- elevens adgang til at blive hørt og udøve kritik af læreren.

- elevens medbestemmelse i mange forhold i klasselivet.

- en insisteren på fællesskabet i klassen - som ses både som noget positivt og noget negativt.

- en lærerstand, der har en u-elitær, uakademisk professionsopfattelse med skepsis over for at udøve sit virke på forskningsbaserede resultater. 
2. Dernæst hævdes det, at man kan finde tydelige spor på den grundtvigske indflydelse i skolens leringsmetoder - især ved, at:

- mundtligheden og fortællingen har en stærk plads i 'læringsrummet'.

- undervisningen er praksisnær.

- test, prøver og eksaminer nedprioriteres.

- undervisningen er antiautoritær.

- der er ligestilling af hoved og krop.

3. Skolens dannelsesopgave, som den f.eks. kommer til udtryk i folkeskolelovens formål og i de faglige formål, ses også som præget af grundtvigsk tankegang. Det viser sig ved, at der er fokus på, at:

- skolen skal understøtte elevernes livsduelighed.

- skolen skal gøre eleverne til kritiske, selvstændige, demokratisk indstillede samfundsborgere.

- skolen skal opbygge historie- og kulturbevidsthed samt nationalfølelse hos eleverne.

- skolen skal forstå sig som et "minisamfund" og skoletiden som et livsafsnit med egenværdi.

- skolen skal fremme elevernes forståelse for fællesskab og lighed mellem mennesker.

4. Endelig kan man se den grundtvigske tankegangs indflydelse i en række strukturelle forhold. Dette kommer til udtryk ved, at:

- skolegang er gratis i Danmark.

- den danske skole er en enhedsskole.

- skolen er en kommunal skole med stor lokal forældreindflydelse.

- vi har undervisningspligt og ikke skolepligt.

Hvorvidt disse forestillinger om Grundtvigs indflydelse på folkeskolen faktisk kan verificeres gennem studier af skolens udvikling, vil som sagt ikke bliver behandlet her. Der er til dato ikke publiceret nogen systematisk studie af sammenhængen mellem Grundtvig og folkeskolen, som kan belyse spørgsmålet. Det interessante i forbindelse med nærværende myteundersøgelse er imidlertid heller ikke at anskue forestillingerne eller myten i et 'sandhedsperspektiv', men netop i et 'funktionsperspektiv'. 


\subsection{Hvilke påvirkningsveje angives?}

Interviewpersonerne blev også interviewet om deres opfattelse af, hvordan de grundtvigske tanker har øvet indflydelse på folkeskolen. I den forbindelse nævntes følgende påvirkningsveje: kulturen/mindset'et, lærerne, læreruddannelsen, seminarielærernes baggrund, Danmark Lærerforenings professionsidealer, den grundtvig-koldske skoletradition, folkeoplysningen, højskolebevægelsen, Dansk Skoleforening, undervisningsministrenes handlinger, lovgivning/udvalgsarbejde, folkeskolens formålsparagraf, folketingspolitikere, embedsmænd, undervisningsmateriale i skolen og morgensangen på skolen. Samler man udsagnene, kan de angivne påvirkningsveje sammenfattes i seks kategorier og vægtes efter, hvor mange interviewpersoner der nævner dem:

- lærerne via deres uddannelse og organisationer

- minister og folketing

- den grundtvigske skoletradition uden for folkeskolen 5

- kulturen/'mindset'et i almindelighed 4

- embedsmænd

- morgensang og uv-materiale

Ser man på fordelingen af kategorierne $\mathrm{i}$ forhold til de enkelte interviewperson-grupper, er der intet signifikant fordelingsmønster af svarene, men det er markant, at især larerne og det politiske niveau fremhæves. I relation til sidstnævnte fremhæves også klart, at det først og fremmest er undervisningsministrenes indflydelse, der gør sig gældende.

Det er bemærkelsesværdigt, at ingen af de interviewede nævner noget om, hvorfor påvirkningsvejen er, som de mener, den er. De nævner alene, hvordan påvirkningen er foregået. Selv om der i interviewet ikke blev stillet spørgsmål om 'hvorfor', kunne man have forestillet sig, at 'et hvordan' og 'et hvorfor' ikke kunne adskilles hos disse personer, som alle kan betegnes som intellektuelle, der er vant til at tænke sammenhængende og overordnet. Når sammenhængen mellem 'hvordan' og 'hvorfor' ikke umiddelbart etableres af interviewpersonerne, og der ikke anlægges en kritisk vinkel på opfattelsen af påvirkningsvejen, er det formentlig et udtryk for den afideologiserende udvikling, der skete med de videnskabelige diskurser i 1990'erne og frem. På baggrund af et overforbrug af forskellige 
kritikformer såsom ideologikritik, statskritik, fagkritik blev tendensen til det modsatte - dvs. til slet ikke at spørge 'hvorfor' - fremtrædende. Dette forhold er i høj grad - også i denne sammenhæng - med til at underbygge mytens mulighed for at blive til "natur" og udfolde sig bag ryggen af mennesker (jf. Roland Barthes' analyser).

I forbindelse med indflydelsesvejene er det igen vigtigt ikke at skelne mellem 'Grundtvigs tanker' og 'de grundtvigske tanker', men lade dem i denne sammenhæng komme ud på et. Når analysen nemlig sker i forhold til det praktiske niveau i børneskolen, altså folkeskolen, må opmærksomheden være på, at Grundtvig, som nævnt tidligere, kun gjorde sig ganske få tanker om børneskolen - mest udbygget i skriftet "Statsmæssig Oplysning” (1834). Hans direkte indflydelse på en børneskolepraksis har derfor været meget begrænset. Det var gennem Christen Kold og hans arvtagere, at Grundtvigs tanker blev tolket og fik indflydelse. De blev tolket og omsat til praksis gennem den grundtvig-koldske skoletradition, som den kom - og kommer - til udtryk i friskolen, efterskolen og højskolen.

\subsection{Mytens funktion}

Som eksemplificeret tidligere, er det almindeligt, at en myteafdækning forfølger et sandhedsperspektiv. Ønsket er at afsløre, hvordan der er blevet taget fejl i historieskrivningen, og afsløringen sker herefter gennem et større eller mindre verificeringsarbejde. I nærværende undersøgelse er myteafdækningen som flere gange antydet mere relevant i et funktionsperspektiv og derigennem til at få besvaret spørgsmålene: Hvad er mytens indhold? Hvem har brugt myten? Og med hvilket sigte og resultat? Først en lille ekskurs.

\section{Ekskurs}

Det lader sig nemt bekræfte uden for interviewundersøgelsen, hvorfor funktionsperspektivet er mere relevant. En tilfældig søgning på Google på sætningen, "Grundtvigs indflydelse på folkeskolen” resulterede f.eks. i tre udsagn, som på eksemplarisk vis illustrerede forskellige måder at anvende Grundtvig på: 
Under overskriften "Mindre Grundtvig, mere arbejdsdisciplin" skriver direktør på Campus Vejle, Morten Weiss-Pedersen, den 19. maj 2011 på Undervisningsministeriets hjemmeside i et stafetindlæg om ungdomsuddannelsernes konkurrence med Fjernøstens unge:

De unge i ungdomsuddannelserne i Danmark skal på den konkurrencebaggrund være mindst lige så kompetente som de unge i Fjernøsten. Ellers er der sorte udsigter for vores velfærdssystem. Derfor skal faglighed, arbejdsdisciplin og metode tilbage som fikspunkterne i undervisningen, og fokus skal flyttes væk fra de mere bløde værdier og den laissez faire-holdning, som præger skolerne, hvor gennemførelsestaksameteret vejer tungere end kvalitet, krav og indhold i undervisningen. Når gennemførelsestaksameteret vejer tungest, kan det få den konsekvens, at de dygtige i ungdomsuddannelserne også lades tilbage og ikke når det optimale af deres kunnen. Så lidt mindre Grundtvig og mere fokus på de klassiske dyder er vejen frem. ${ }^{8}$

Her sættes Grundtvig lig med fokusering på bløde værdier og laissez faireholdning samt manglende arbejdsdisciplin. Denne holdning kom som bekendt også til udtryk hos de tre interviewede pædagogiske forskere. Grundtvigs virkningshistorie har også betydet, at "faglighed, arbejdsdisciplin og metode" har været fraværende i ungdomsuddannelserne, men de bør ifølge artiklen komme "tilbage som fikspunkterne i undervisningen”. Om det virkeligt forholder sig sådan, at Grundtvigs pædagogiske tankegods har haft denne efter forfatterens opfattelse negative funktion, er ikke godtgjort i artiklen, hvilket må betyde, at forfatteren antager sin egen grundtvigreception som en, han har fælles med læseren. Grundtvig er her absolut en negativ referencefigur.

En anden post henviste til et foredrag med titlen "Frihed og fællesskab - arven efter Grundtvig” af daværende statsminister Lars Løkke Rasmussen, som afholdtes på Vartov den 11. januar 2011 (refereret på statsministeriets hjemmeside og i bogen Fri, friere, Grundtvig). Løkke Rasmussen siger i foredraget bl.a.:

\footnotetext{
${ }^{8}$ http://www.uvm.dk/Uddannelser/Paa-tvaers-af-uddannelserne/Stafetten/Stafetten-27-Morten-Weiss-Pedersen
} 
Der er mange, der har fortolket Grundtvig. Han var i strid med sig selv og sine omgivelser. Og han var stærkt engageret i sin tid og sin omverden. Han udviklede sine tanker. Men det betyder ikke, at man kan bruge ham til hvad som helst. Grundtvig skelner mellem lærdom og dannelse, altså læren om livet. Det er en tanke, der har været så elsket, at vi på grund af den var i fare for at miste lærdomsskolen. Grundtvig har sejret ovenud i vores folkeskole, hvis det altså er ham, der har sejret, og ikke en filtreret eftertids-udgave. Faglighed blev i en periode et fyord mange steder og blev næsten oplevet som det grundtvigskes modsætning. Det er her jeg mener, at Grundtvig har fået sat filter på, og at Grundtvig uden filter er både mere interessant og nuanceret (...) Og vi skal holde fast i vores styrker. Men er det nok til at ruste børnene til at være gode demokratiske - og for den sags skyld grundtvigske - borgere? Her skal vi tage filteret af: I den moderne og globaliserede verden er der ingen vej uden om de hårde boglige kundskaber. Her er vi også nødt til at være med (...) Elevplaner og test er redskaber til, at læreren kan møde den enkelte elev og frisætte elevens potentiale - det er for mig at se helt i Grundtvigs ånd (Gade Jensen m.fl. 2011, 27-29).

Her anvendes Grundtvig utvetydigt til at legitimere test og elevplaner (de er "helt i Grundtvigs ånd") - men Løkke Rasmussen mener samtidig, at det grundtvigske har været medårsag til, at fagligheden er mistet eller er blevet underprioriteret i folkeskolen. Når Grundtvig bliver medskyldig i denne underprioritering, så skyldes det efter Løkke Rasmussens mening, at Grundtvig i eftertiden er blevet misforstået, og at der kun er kommet "en filtreret" Grundtvig ud af det. Grundtvig er her en betinget positiv referencefigur. Han er nemlig kun positiv, hvis han tolkes rigtigt, underforstået: som Løkke Rasmussen gør det.

En tredje post henviste til en passage under overskriften "Grundtvig har ordnet paragrafferne” på hjemmesiden Folkeskolen.dk. Der er tale om et journalistisk referat af, hvad filosoffen Jørgen Husted (JH), lektor ved Aarhus Universitet, har sagt på et møde arrangeret af Danmarks Lærerforening. På mødet udtaler Husted sig om Grundtvigs indflydelse på folkeskolen:

"Allerede Grundtvig gjorde nemlig op med den liberale skole, som han kaldte den sorte skole. Ud med de døde kundskaber og ind med det 
levende ord, sagde Grundtvig og Kold. Skolen skulle være for livet, ikke for skolen selv, og den skulle være for alle. Den skoleforståelse har siden præget lovgivningen i Danmark, kulminerende med 1958-skoleloven, der indførte enhedsskolen i Danmark. Grundtvigs mål var, at skolen skulle forberede eleverne til et jævnt og muntert, virksomt liv på jord. Skolen skulle forsøge at gøre dem til selvstændigt tænkende, oplyste mennesker”, siger Jørgen Husted. Den økonomiske nødvendighed, der presser mange andre lande til at ændre deres uddannelser fra "elfenbenstårns-uddannelser” til "anvendelsesuddannelser”, lægger således ikke samme pres på den danske folkeskole, for vi har jo taget det opgør for længe siden (...) der er al mulig grund til at bevare den nuværende formålsformulering [fra 1975], som udtrykker det unikke danske skolesyn, mener Husted (Folkeskolen.dk (nr. 03, 2006).

For Husted 'kulminerer' Grundtvigs indflydelse med indførelsen af enhedsskolen, og han anser det for en grundtvigsk indflydelse, at man i Danmark tænker meget på skolelærdommens forbindelse til dagliglivet, dvs. at viden skal kunne bruges til noget, der kan gøre vores liv bedre. En 'anvendelsesuddannelse' kalder Husted det. Grundtvig bruges her eksplicit til at modarbejde en ændring af folkeskolens formålsparagraf fra 1975-loven. Da udtalelserne er fremkommet på et stort fællesmøde arrangeret af Danmarks Lærerforening med henblik på en drøftelse af behovet for evt. ændringer af formålsparagraffen, må Husted gå ud fra, at henvisningen til Grundtvig er et positivt og slagkraftigt argument. Grundtvig er her en absolut positiv referencefigur.

Går vi tilbage til interviewundersøgelsen, viser analysen af omtalen af Grundtvig hos interviewpersonerne, at 17 ud af de 20 personer opfatter Grundtvig som en positiv referencefigur. Én ser ham som en betinget positiv referencefigur, og to opfatter Grundtvig som en negativ referencefgur. Sidstnævnte to er begge blandt de tre pædagogiske forskere, der blev interviewet. Det negative, der ligger i Grundtvigs indflydelse, er for begge disse interviewpersoner, at de grundtvigske pædagogiske tanker har skabt en skole, hvor det faglige (vidensbaseringen) får en for underordnet plads i forhold til andre forhold i skolen (f.eks. opbygningen af fællesskab), og at lærerne har en antiakademisk, antieksperimentel og antiprofessionel holdning til deres arbejde. 
Det er dog interessant at konstatere, at Grundtvig stadig langt overvejende bliver opfattet som en positiv referencefigur, selv om fremtrædende skoleforskere i offentligheden altså har givet udtryk for det modsatte. ${ }^{9} \mathrm{Li}-$ geledes er den positive Grundtvig-opfattelse bemærkelsesværdig på baggrund af, at der i den almindelige skolediskurs - i tråd med 'konkurrencestatstænkningen'10 - ses skævt til at henvise til historien, idet det understreges, at vi må tænke og handle 'fremadrettet'. Opfattelsen af Grundtvig som en positiv referencefigur hænger formentlig ikke mindst sammen med den generelle, betydende funktion, Grundtvig som symbol og myte har haft på opbygningen af dansk identitet, et forhold, der vil blive udfoldet yderligere i artiklens afslutning.

\subsection{Mytebrugen}

Der skal nu redegøres for den specifikke og individuelle brug af myten hos interviewpersonerne. Resultatet kan opgøres på følgende måde:

a. 14 interviewpersoner bruger myten til at underbygge eget skolesyn og/eller modsige andres

Denne måde at anvende myten på sker på to måder:

- direkte ved, at den interviewede hævder at være påvirket af Grundtvig, der således tages til indtægt for et synspunkt, der svarer til vedkommendes eget.

- indirekte ved, at personen i beskrivelsen af det vigtigste ved Grundtvigs pædagogiske tanker samtidig angiver sin egen opfattelse af, hvad der er vigtigt i skolen. Uden at eksplicitere en direkte forbindelse får interviewpersonen på den måde opskrevet betydningen af sin egen

${ }_{9}$ Der kan f.eks. henvises til professor Peter Dahler Larsen, SDU, og professor Lars Qvortrup, ÅU, som hver især flere gange offentligt har givet udtryk for det uheldige $\mathrm{i}$, at Grundtvigs tanker har haft - og stadig har - indflydelse på folkeskolens udvikling.

${ }^{10}$ Jf. Ove Kaj Pedersens fremragende analyse af tendenser i den nutidige skoletænkning i bogen Konkurrencestaten (Pedersen 2011, 169-204). 
opfattelse. Det er klart, at denne mekanisme fordrer, at man opfatter Grundtvig som en absolut positiv referencefigur.

\section{b. 6 interviewpersoner bruger myten til at fremme bestemte personlige interesser}

Disse personlige interesser fordeler sig på 4 forskellige områder:

- til fremme af professionspolitiske interesser Et eksempel: En interviewperson hævder, at Grundtvig mener, at lærerpersonen har en helt afgørende betydning for livet i skolen. På den måde bliver det autoriseret, at læreren er en helt central og afgørende person i skolen, og ingen skoleudvikling kan ske, uden at læreren bliver involveret.

- til personlig faglig profilering

Et eksempel: En interviewperson anvender Grundtvig til at underbygge sit eget billede af Danmarks udvikling (nationsbygningen) og sin egen nye og særlige definition af det danske samfund, som vedkommende i mange kredse har høstet megen ære af.

- til fremme af bestemte faglige synspunkter

Et eksempel: Forestillingen hos en interviewperson om Grundtvigs (negative) indflydelse bruges til at udstille skolen og lærerne. Derigennem fremhæves vigtigheden af vedkommendes eget budskab om, at den danske skole skal være mere fagorienteret og rationel i sin virksomhed.

- til et personligt opgør med det grundtvigske

Eksempel: En interviewpersons forestilling om, at Grundtvigs indflydelse kun var meget lille i modsætning til, hvad de (efter personens opfattelse) 'selvfede' grundtvigianere tror, anvendes til et personligt opgør med det grundtvigske.

\section{c. 3 interviewpersoner bruger myten til at legitimere egne handlinger}

Eksempel: Legitimeringen af egne handlinger kommer til udtryk ved, at der bruges vendingen: "Hvis Grundtvig havde levet i dag, så ville han 
mene XXX eller gøre XXX” - ligesom jeg (personen selv) mener eller har gjort.

\section{d. Myten bruges nøgternt, faktuelt og uden hensigt}

I tre tilfælde har det ikke været muligt at spore, at interviewpersonens myte om Grundtvigs indflydelse har anden hensigt end at ville udtrykke noget nøgternt og faktuelt. Når disse personers forestillinger om Grundtvigs indflydelse alligevel får mytens karakter, er det, fordi ingen af dem kan dokumentere denne indflydelse.

Undersøgelsen af den specifikke og individuelle brug af myten hos interviewpersonerne viser, at der samlet set er en nær sammenhæng mellem opfattelsen af Grundtvig som en positiv referenceperson og det billede, der har tegnet sig af den specifikke anvendelse af myten. Det er kun i ganske få tilfælde, at myten anvendes som modbillede til det, man selv mener. Myten om Grundtvigs indflydelse i folkeskolen anvendes langt overvejende til at tegne et medbillede. Det vil sige til at fremhæve forhold, der i øvrigt af den person, der anvender myten, opfattes positivt.

\section{Konklusion på undersøgelsen}

Arbejdet med myteundersøgelsen i nærværende undersøgelse fordrede indledningsvis en afklaring og eksplicitering af det mytebegreb, der ville blive anvendt. Resultatet af disse overvejelser mundede ud i den opfattelse, at myten altid vil være et konglomerat af et virkelighedsgrundlag (af noget som i positivistisk forstand vil være sandt) og en ideologisk funktion. Myten kan først få afgørende virkning, hvis det er muligt, at 'der kan være noget om snakken', altså hvis en umiddelbar tolkning af virkelighedsgrundlaget ikke modsiger mytens indhold. Ligeledes er mytens virkningskraft afhængig af, at det er vigtigt for den person, der skaber myten, at få den etableret og bevidst eller ubevidst at kunne bruge den i sit virke. Det bliver på den måde afgørende, at der er et indre forhold mellem personens holdninger og mål og mytens indhold.

På den baggrund undersøgtes en række udvalgte personers opfattelse af Grundtvigs indflydelse i folkeskolen. Tilbage står nu spørgsmålet, om 
der faktisk er tale om en myte i ovennævnte forstand i de forestillinger, interviewpersonerne har gjort sig. Det mener jeg i lyset af undersøgelsen, det er muligt at argumentere for.

For det første er de indflydelsesområder, som interviewpersonerne nævner som præget af grundtvigsk tankegang, af en sådan kategorial art, at en forestilling om, at de kan være grundtvigsk påvirket ikke umiddelbart vil blive modsagt. Det er en del af indforståetheden i skolediskursen, at f.eks. skolens kultur er udtryk for en bestemt måde at tænke om, hvordan forholdet mellem mennesker (børn og lærere og børnene indbyrdes) bør være. Der er således allerede etableret en forståelsesfigur, som kæder skolekultur og menneskesyn sammen. At opfatte dette menneskesyn som grundtvigsk præget vil altså ikke umiddelbart blive modsagt af en gængs måde at forstå skolevirksomhed på. På samme måde vil heller ikke de øvrige indflydelsesområder give anledning til umiddelbar modsigelse.

Hvordan det så forholder sig med sammenhængen mellem grundtvigsk pædagogisk tænkning og de nævnte indflydelsesområder, er ikke afklaret med denne undersøgelse, da det ikke er afgørende for mytedannelsen, at 'myteproducenten' ved noget faktuelt om påvirkningen inden for de fem indflydelsesområder. Det, der betyder noget, og som er motoren i myteproduktionen, er, hvad etableringen af myten bruges til.

For det andet anvender stort set alle interviewpersonerne myten om Grundtvigs indflydelse i folkeskolen til at fremme forhold, som ikke i egentlig forstand har forbindelse til myten. Forestillingerne om grundtvigsk indflydelse har altså tydeligvis en ideologisk funktion. Konklusionen er derfor i forhold til udgangstesen, at der findes en forestilling om Grundtvigs indflydelse i folkeskolen, som med rette kan betegnes som en myte.

Den omstændighed, at den faktuelle viden om Grundtvigs virkningshistorie i folkeskolen er så begrænset, som den er hos interviewpersonerne (selv hos skolehistorikerne og Grundtvig-forskerne), og at de på trods af denne begrænsede viden etablerer eller tilslutter sig myten om Grundtvigs indflydelse, fører til opstillingen af følgende tese: Myten om, at Grundtvig har haft indflydelse på folkeskolens udvikling, har storre indflydelse på folkeskolens udvikling, end Grundtvig har haft. Nærmere bestemt får interviewpersoners forestilling om Grundtvigs indflydelse på skolen dem til at handle (med den betydning netop deres handling har), som om Grundtvig har haft indflydelse. Deres handlinger bliver grundtvigske, men i deres egen forståelse af, hvad der er grundtvigsk. 


\section{Thorstein Johannes Balle}

Om denne nye tese faktisk holder, må afklares af videre undersøgelser, men man kan med baggrund i tesen udvide forståelsen af, hvordan begrebet Grundtvigs virkningshistorie i folkeskolen kan opfattes, så det omfatter tre påvirkningskilder:

1. Grundtvig selv, som han handlede og skrev. Her er tale om den påvirkning, som Grundtvig selv gennem tekster og handlinger forsøgte at udøve på den daværende børneskole. Hans produktion af tekster om skole og oplysning er imidlertid også blevet og bliver brugt som direkte inspirationskilde. Dette sker naturligvis på baggrund af en given aktuel fortolkning af hans liv og tekster, men påvirkningen er fra den oprindelige kilde, så at sige.

2. Grundtvigs arvtagere, som de handlede og skrev. Med Grundtvigs arvtagere som påvirkningskilde tænkes først og fremmest på de mennesker, der blev tilknyttet den grundtvig-koldske skoletradition i de frie skoler, men også på de seminariefolk, der gennem historien har været med til at uddanne lærere. Mange fra denne sidste gruppe har gennem deres arbejde i ord og handling formidlet de grundtvigske pædagogiske tanker til de studerende, som senere blev lærere i folkeskolen. Grundtvigs arvtagere er således også mange af folkeskolens lærere og ledere. Dertil kommer de politikere, forskere og samfundsdebattører, som gennem årene har deltaget $\mathrm{i}$ den skolepolitiske diskurs og beslutningstagen og forfægtet grundtvigske synspunkter. For alle arvtagerne gælder det imidlertid, at de har virket på grundlag af netop deres Grundtvig-reception.

3. Grundtvigmyten. Grundtvigmyten som kilde til påvirkning etableres ved, at centrale personer i den skolepolitiske debat og beslutningstagen har en forestilling om, hvilken indflydelse Grundtvig har haft. Denne forestilling bliver herefter styrende for de beslutninger og handlinger, disse personer foretager sig. Som baggrund for denne forestilling er der naturligvis en mere eller mindre bevidst opfattelse af, hvad Grundtvig mente, men denne opfattelse bygger ikke på kendskab til endsige studier af Grundtvigs tekster.

Det interessante ved sidstnævnte påvirkningskilde er altså, som det er påvist $\mathrm{i}$ artiklen, at mytens indhold ikke behøver at have nogen særlig 
tilknytning til Grundtvig, men at det ikke desto mindre betegnes som grundtvigsk. Grundtvig får altså i denne sammenhæng i udpræget grad den symbolske funktion, som Jes Fabricius Møller fremhæver i sin bog fra 2005. Når det drejer sig om folkeskolen, kan, som det er beskrevet, den emotionsmotiverende og handlingsanvisende myte alene bygges op om symbolet 'Grundtvig', og på den måde er Grundtvigs indflydelse måske slet ikke Grundtvigs!

\section{Afslutning}

Som angivet i forbindelse med artiklens indledningscitat måtte middagsværtens forestilling om Grundtvigs virkningshistorie have en anden baggrund end kendskab til Grundtvig og folkeskolen. Historikeren Uffe Østergaard har flere gange meget præcist udpeget denne anden baggrund, der må være virksom, når personer uden faktuelt kendskab til Grundtvig, får en forestilling om hans indflydelse. Østergaard siger i sin bog Europas Ansigter:

Det er (...) grundtvigianismens præmisser, som er blevet lagt til grund for den politiske (ud)dannelse i dette land. Det er lykkedes dem at præge deres modstandere bag om deres egen selvforståelse. For mig at se er deres ideologi blevet noget før-bevidst, noget "naturligt" (i grunden burde vi vel sige noget kulturligt), som ikke modsiges, fordi deres program er kommet til at definere hele danskheden. Det gælder for hele den herskende elite, de borgerlige såvel som arbejderbevægelsen, uanset hvordan de er blevet rekrutteret (Østergaard 1998, 77-78). ${ }^{11}$

En anden historiker, professor Knud J.V. Jespersen, udtrykker i sin bog $\mathrm{Hi}$ storien om danskerne 1500-2000 (Jespersen 2007) en lignende tankegang. I sin beskrivelse af baggrunden for Grundtvigs tænkning skriver han således:

Alle disse store idestrømninger [i Europa på Grundtvigs tid] bidrog hver på deres måde til at forme hans tankeverden og dermed også til udform-

11 Østergaards brug af begrebet "naturligt" om den grundtvigske tænknings indflydelse er her ganske parallel med Roland Barthes. 
ningen af den særlige danske -isme - grundtvigianismen - der måske i endnu højere grad end århundredets store europæiske -ismer af politisk og ideologisk karakter fik afgørende betydning for danskerne og for vor måde at indrette os på (Jespersen 2007, 46).

Senere i samme værk hedder det:

På næsten alle tænkelige områder har de ideer, der i en bestemt historisk situation midt i 1800-tallet udvikledes af Grundtvig og hans kreds, sat sig dybe spor i dansk tænkemåde og i den måde, det danske samfund den dag i dag fungerer på (ibid. 154).

Disse udtalelser bekræfter i mangt og meget den her foretagne unders $\emptyset$ gelse. Grundtvigianernes ideologi, som Østergaard kalder det, er blevet til en indforståethed, en fælles for-dom, i danskernes opfattelse af det danske samfund i en sådan grad, at Grundtvigs påvirkning kan beskrives som en selvfølgelighed selv hos folk, der slet ikke kender noget nærmere til Grundtvigs skrifter og tanker. Grundtvig er blevet til et symbol. Denne selvfølgelighed og forforståelse, viser undersøgelsen, ligger i lige så høj grad til grund for de forestillinger, som mennesker, der arbejder med folkeskolen i forskningsmæssig, politisk eller praktisk sammenhæng, har, med mindre de konkret gennem forskning er gået bag selvfølgeligheden og for-dommen og har undersøgt den.

Hvad angår den særligt danske indforståethed, er det tankevækkende, hvordan næsten alle interviewpersonerne (15 ud af 20) på et eller andet tidspunkt $\mathrm{i}$ interviewet drog deres egen person og egne erfaringer med det grundtvigske ind i deres redegørelse for Grundtvigs indflydelse. Det var, som om selve interviewtemaet i sig selv ansporede til en personlig, næsten identitetsmæssig forholden sig til sagen. En af de personer, der opfattede Grundtvigs indflydelse som negativ, fortalte f.eks. indgående, hvordan vedkommende gennem sin opvækst fik et meget negativt, nærmest fjendsk forhold til det lokale grundtvigske "kleresi". Om der er en sådan ubevidst psykologisk sammenhæng mellem interviewtemaet og interviewpersonerne, altså om der til indforståetheden også hører en følelsesmæssig dimension, der ægger til et for eller imod, kan undersøgelsen ikke svare på, men bemærkelsesværdig var denne tendens til at personliggøre interviewtemaet. 
Der er ni år mellem de citerede to historikeres udsagn om grundtvigianismens indflydelse på det danske samfund, men deres konklusioner er meget ens. Set i relation til myteundersøgelsen bliver tidsafstanden interessant, idet Uffe Østergaard meget bastant i sin bog fra 1998 siger:

Det land der kommer ud af 1980'ernes og 90'ernes omvæltninger er ikke Grundtvigs fædreland. Den mytologi han var en vigtig bestanddel af er i hastig opløsning, og det er på høje tid at gøre sig klart, at dens rammer er fortidige og fiktive. Derfor er det vigtigt at anskue Grundtvig og grundtvigianisme i deres præcise historiske sammenhæng. Kun derved kan man som danske skelne mellem de levende myter og de døde. For vi har dem med os alle sammen endnu, også det store flertal, der ikke selv er klar over det (Østergaard 1998, 83).

Citatet af historikeren Knud V.J. Jespersen, som altså er fra 2007, fremholder imidlertid, at grundtvigianismens grundlæggende indflydelse på samfundets tænkemåde og indretning stadig er gældende. På tilsvarende måde viser den undersøgelse, der her er præsenteret, at myten om Grundtvigs indflydelse i folkeskolen hverken er død eller i opløsning - end ikke hos mennesker, der beskæftiger sig professionelt og videnskabeligt med folkeskolen.

\section{Forkortelser}

GSkv I-II Bugge, K.E. (udg.) (1968), Grundtvigs skoleverden i tekster og udkast, 1-2, København.

US I-X Holger Begtrup (udg.) (1904-1909), Nik. Fred. Sev. Grundtvigs Udvalgte Skrifter, I-X, København.

\section{Litteratur}

Barthes, Roland (1970), Mytologier, København.

Baunvig, Katrine Frøkjær (2010), "Ude af øje, ude af sind - hvad gør man når myten skal under huden?” i Religionspadagogisk Forum, 2010, nr. 2, 30-39.

Bryld, Claus (2001), Kampen om historien, (del 3 og 4), Roskilde. 


\section{Thorstein Johannes Balle}

de Certeau, Michel (1975), Spor af historien, København.

Eriksen, Anne (1999), Historie, minne og myte, Oslo.

Eriksen, Thomas Hylland (1996), Kampen om fortiden, Oslo.

Gadamer, Hans-Georg (1986), Sandhed og metode - grundtrek af filosofisk hermeneutisk, Aarhus.

Hermansen, Mads (2001), Den fortallende skole - om muligheder i skoleudvikling, Aarhus.

Jacobi, Finn (1988), Myte som sandhed, Aarhus.

Jensen, Henrik Gade m.fl. (red) (2011), Fri, friere Grundtvig, København.

Jespersen, Knud V.J. (2007), Historien om danskerne 1500-2000, København.

Jørgensen, Stig (1994), Den kollektive myte - Midtpunktskommentar fra JyllandsPosten 14.10.94.

Kofoed, Niels (1968), Myte og intellekt, København.

Korsgaard, Ove (1998), Kampen om lyset, København.

Kruse, Tove Elisabeth (red.) (1998), Bud på historien, Roskilde.

Larsen, Esben Lunde (2012), Frihed for Loke sàvel som for Thor, København.

May, Rollo (1992), Myte og eksistens, København.

Mentz, Jørgen og Mørch, Søren (1975), Myte eller realitet i danmarkshistorien, København.

Mortensen, Jacob Kjærsgaard (2004), Nyde som man nemmer - Grundtvig i et fortolknings-, receptions- og brugshistorisk perspektiv, (upubliceret speciale fra DPU), april 2004.

Møller, Jes Fabricius (2005), Grundtvigianisme i det 20. århundrede, København.

Pedersen, Ove Kaj (2011), Konkurrencestaten, København.

Poulsen, Jens Aage (2010), “Myter i historien - eller er historien myter?”, i Religionspedagogisk Forum 2010, nr. 2.

Sundqvist, Oluf og Svalastog, Anna Lydia (1997), Myter og myteteorier, Uppsala.

Sørensen, Niels Arne (2005): “Om myter og historie”, i Lars Bisgaard og Sven Rask (red.), Fynske Myter, Odense.

Thomsen, Kristoffer Raun (2011), “Myter overtrumfer virkeligheden”, i Retorikmagasinet 2011, nr. 82.

Undervisningsministeriet (2007), Skolen for livet - møderapport fra Sorømødet 2007, København.

Wind, H.C. (1987), Historie og forståelse - filosofisk hermeneutik, Aarhus.

Østergaard, Uffe (1998), Europas ansigter, København. 